\title{
EVALUATION OF REPRODUCTIVE PERFORMANCE ON LARGE-SCALE HUNGARIAN DAIRY FARMS
}

\author{
L. Ózsvári, I. Fodor \\ ozsvari.laszlo@univet.hu
}

University of Veterinary Medicine, István út. 2, Budapest, 1078, Hungary

The aim of our study was to survey the reproductive performance of replacement heifers and cows in large commercial dairy herds by collecting the most commonly used reproductive indices and to introduce novel parameters to evaluate fertility in dairy units.

The authors surveyed the major reproductive indices on 34 large commercial dairy farms from all the statistical regions in Hungary between May and November 2015. Individual data were gathered for 50,396 heifers first inseminated between 1 January 2011 and 31 December 2014, and for 25,672 cows that calved between 1 January 2014 and 31 December 2014 in the surveyed herds. The number of cows covered 14.6\% of the total Hungarian milk recorded Holstein-Friesian cow population.

The average ( \pm standard deviation) age at first service, age at first calving and average first service conception rate (CR1) were $15.53 \pm 1.59$ months, $25.61 \pm 2.22$ months and $47.10 \%$, respectively. $8.6 \%$ of the inseminated heifers were culled prior to first calving, at 23.94 3.95 months of age, on average. For cows, calving interval (CI) was 435 days (392-490), CR1 was 26.52\% (11.26-51.40\%), and services per conception (SPC) was 4.04 (2.56-6.16), respectively. The breeding interval (IBI) was 31.38 days (22.00-56.03), and the proportion of reproductive culling was $31.68 \%$ out of all premature disposals (7.57-69.70\%), on average.

The use of some relevant parameters (PR, CRI, CCI) is enough for the daily routine, but in-depth analysis is required when the reproductive performance is diminishing.

Keywords: DAIRY CATTLE, REPRODUCTION, REPRODUCTIVE PARAMETERS, PREGNANCY RATE, CALVING INTERVAL

Milk is the primary source of income on commercial dairy farms. In turn, milk production is fundamentally influenced by reproductive performance [13]. In order to evaluate reproduction effectively, adequate reproductive parameters are required [10]. However, evaluation of reproductive performance may vary from farm to farm, because of the lack of consistency in the usage of the reproductive indices [6]. Therefore, the aim of our study was to survey the reproductive performance of replacement heifers and cows in large commercial dairy herds by collecting the most commonly used reproductive indices and to introduce novel parameters to better standardize the evaluation of fertility in dairy units.

\section{Materials and methods}

The major reproductive indices were surveyed on 34 large commercial dairy farms from all the statistical regions in Hungary between May and November 2015. The average herd size was 755 dairy cows $(291-2,502)$ and the average 305- day milk yield was $10,014 \mathrm{~kg}(8,330-12,541)$. Individual data were gathered for 50,396 heifers first inseminated between 1 January 2011 and 31 December 2014, and for 25,672 cows that calved between 1 January 2014 and 31 December 2014 from the farm management software RISKA (Systo Ltd., Hungary) in the surveyed herds. The number of cows covered $14.6 \%$ of the total Hungarian milk recorded Holstein-Friesian cow population. Data were managed in Microsoft Excel 2013 (Microsoft Corporation, Redmond, WA, USA). Statistical analyses were performed in $R$ version 3.3.2 [15].

\section{Results and discussions}

In heifers, age at first service (AFS), age at first calving (AFC), and first service conception rate (CR1) were the most commonly used parameters. However, the parameters of the culled heifers were rarely considered. The major reproductive indices of heifers are shown in table 1 . The average CR1 of heifers was $47.10 \%$. Altogether, 
The major reproductive parameters of replacement heifers in the studied herds

\begin{tabular}{|l|c|c|}
\hline \multicolumn{1}{|c|}{ Parameter } & Mean & $\begin{array}{c}\text { Standard } \\
\text { deviation }\end{array}$ \\
\hline Age at first service, months & 15.53 & 1.59 \\
\hline Age at first calving, months & 25.61 & 2.22 \\
\hline Days from first service to culling & 246.25 & 107.10 \\
\hline Age at culling, months & 23.94 & 3.95 \\
\hline
\end{tabular}

$8.6 \%$ of the inseminated heifers were culled prior to first calving, at nearly two years of age.

In our study, age at first calving was much higher than 24 months, which is generally considered the optimal AFC from an economic point of view. However, the average AFC has decreased by more than two months in the last two decades in Hungary (fig. 1).

The decrease of AFC is probably attributable to the improvement of heifer management practices, e.g. the implementation of oestrus detection aids $[4,5,15]$. However, since the parameters of the culled heifers were rarely taken into consideration, farm managers were not aware of the economic losses that originated from keeping those heifers, which were culled prior to first calving.

For cows, many conventional reproductive indices were widely used, such as productivity, calving interval $(\mathrm{CI})$, calving-to-conception interval (CCI), services per conception (SPC), CR1, breeding interval (IBI), and the percentage of pregnant cows (PP). The major reproductive parameters of cows are summarized in table 2. Large differences were found among the reproductive performance of cows in different herds, since CI, SPC and IBI ranged from 392 to 490 days, 2.56 to 6.16, and 22.00 to 56.03 days, respectively. The average CR1 was $26.52 \%$ (range: $11.26-51.40 \%$ ). Culling rate of the herds (mean \pm standard deviation) was $29.5 \pm 8.2 \%$. The proportion of reproductive culling was $31.68 \%$ out of all premature disposals (7.57-69.70\%), on average.

The major reproductive parameters of cows in the studied herds

\begin{tabular}{|l|c|c|}
\hline \multicolumn{1}{|c|}{ Parameter } & Mean & $\begin{array}{c}\text { Standard } \\
\text { deviation }\end{array}$ \\
\hline Calving interval, days & 435.2 & 23.7 \\
\hline First service conception rate, \% & 26.52 & 9.41 \\
\hline Services per conception & 4.04 & 0.72 \\
\hline Breeding interval, days & 31.38 & 9.83 \\
\hline
\end{tabular}

Reproductive indices were much poorer than the most frequently used reference values even in the best herds [6]. Calving interval was more than one month longer than 400 days that is often cited as the realistic goal for large dairy herds [1]. In Hungary, CI increased substantially since the 1970s, however, the increasing trend stopped some years ago and now a decrease in CI can be observed (fig. 2). The improvement of the reproductive performance in dairy cows may be related to the widespread implementation of intensive management practices, e.g. transrectal ultrasonography $[3,7,8]$.

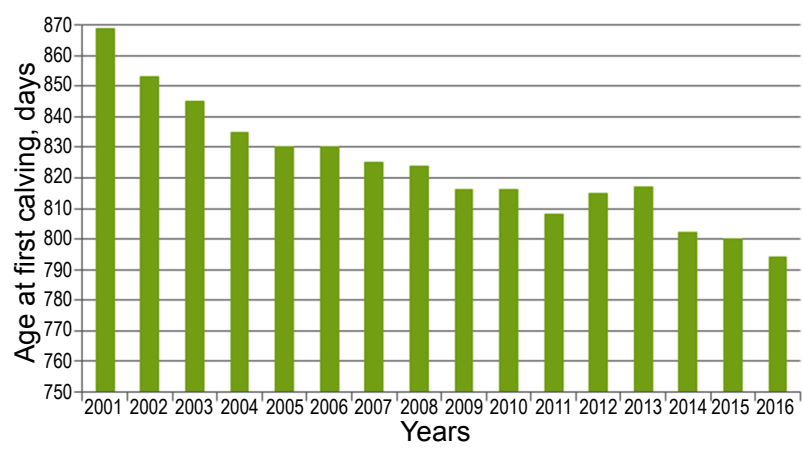

Fig. 1. The average age at first calving in Hungarian dairy herds (2001-2016). Source: National Food Chain Safety Office Livestock Performance Testing Ltd., 2017 [11]

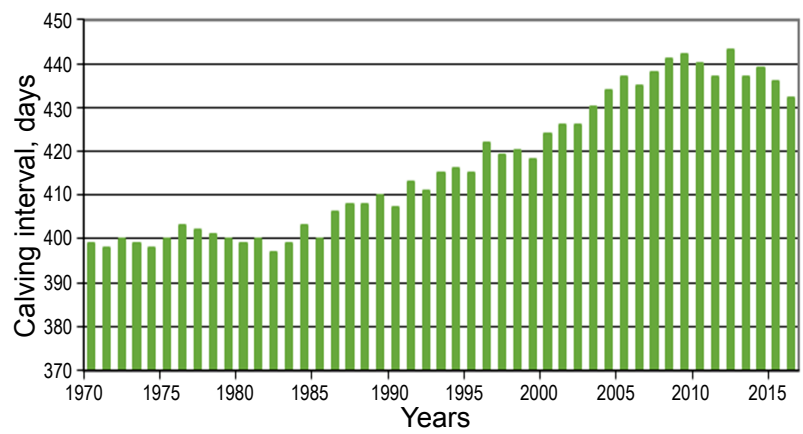

Fig. 2. The average calving interval in Hungarian dairy herds (1970-2016). Source: National Food Chain Safety Office Livestock Performance Testing Ltd., 2017 [11]

However, calving interval should only be used with caution, because this parameter does not take primiparous cows (that make 30-40 \% of the herds) into account. Productivity was also a widely used parameter, although, the method of its calculation is heterogenous among farms. Productivity is originally the number of pregnant cows and those cows that calved in the previous 90 days altogether, divided by the number of cows 
in the herd, expressed as a percentage [10]. Although SPC is an important parameter of fertility, its role should not be overemphasized, because other parameters, e.g. CCI, are more relevant from an economic point of view. Moreover, if the work of inseminators is evaluated based on SPC, they might inseminate only those cows that will be the most likely to conceive, but in turn, CCI will largely increase, causing serious economic losses.

In North America, heat detection rate (HDR), conception rate $(\mathrm{CR})$ and pregnancy rate $(\mathrm{PR})$ are the most commonly used reproductive parameters in dairy herds $[2,12]$. HDR is the number of cows that were inseminated as a proportion of the total number of cows that were eligible for insemination in a 21-day-long period (that is equal to the length of the estrus cycle; [9]. CR is in fact the reciprocal of SPC, and indicates the proportion of successful inseminations (i.e. those that resulted in a pregnancy) within the total number of inseminations. PR is the number of cows that became pregnant as a proportion of those cows that were eligible for insemination during a 21-day-long period. The relationship among HDR, CR and PR can be described by a simple mathematical equation: $\mathrm{HDR} \times \mathrm{CR}=\mathrm{PR}$. Corrected pregnancy rate (cPR), as a novel parameter, was introduced to overcome inaccuracies stemming from the differences of the Hungarian and Northern American culling policies [10]. cPR is the PR calculated for all cows within 200 days in milk. PR and cPR strongly correlate with the traditional measures of fertility, however, carry more relevant and upto-date information about the performance of the herd [10]. Therefore, besides the widely used traditional reproductive parameters, the use of PR and/or cPR would be very beneficial. Reproductive performance must be evaluated taking several indices into account.

\section{Conclusions}

The reproductive performance of replacement heifers and dairy cows is suboptimal on the Hungarian Holstein-Friesian farms, however, significant improvements can be observed in the recent decades. In order to evaluate the changes in performance effectively, reproductive parameters should be tracked on a regular basis. The use of some relevant parameters ( $\mathrm{PR}, \mathrm{cPR}, \mathrm{CR} 1, \mathrm{CCI})$ is enough for the daily routine, but in-depth analysis is required when the reproductive performance is diminishing.

Acknowledgements. The Project was supported by the European Union and co-financed by the European Social Fund: (1) EFOP-3.6.1-162016-00024 "Innovations for Intelligent Specialisation on the University of Veterinary Science and the Faculty of Agricultural and Food Sciences of the Széchenyi István University Cooperation"; (2) EFOP-3.6.2-16-2017-00012 "Development of a product chain model for functional, healthy and safe foods from farm to fork based on a thematic research network"; and (3) EFOP-3.6.3VEKOP-16-2017-00005 "Strengthening the scientific replacement by supporting the academic workshops and programs of students, developing a mentoring process".

1. Farin P. W., Slenning B. D. Managing Reproductive Efficiency in Dairy Herds. In: Radostits O. M. (ed.): Herd Health. Philadelphia, Saunders, 2001, pp. 255-289.

2. Ferguson J. D., Skidmore A. Reproductive performance in a select sample of dairy herds. Journal of Dairy Science, 2013, vol. 96,issue 2, pp. 1269-1289. DOI: $10.3168 /$ jds.2012-5805.

3. Fodor I., Abonyi-Tóth Zs., Ózsvári L. Management practices associated with reproductive performance in Holstein cows on large commercial dairy farms. Animal, 2018, vol. 12, issue 11, pp. 2401-2406. DOI: $10.1017 /$ S1751731118000101.

4. Fodor I., Baumgartner W., Abonyi-Tóth Zs., Lang Zs., Ózsvári L. Associations between management practices and major reproductive parameters of Holstein-Friesian replacement heifers. Animal Reproduction Science, 2018, vol. 188, pp. 114-122. DOI: 10.1016/j.anireprosci.2017.11.015.

5. Fodor I., Baumgartner W., Monostori A., Abonyi-Tóth Zs., Ózsvári L. Dairy heifer reproductive management and performance on large Hungarian commercial farms. Magyar Állatorvosok Lapja, 2018, vol. 140, issue 2, pp. 67-74.

6. Fodor I., Búza L., Ozsvári L. Reproductive management and major fertility parameters of cows in largescale Hungarian dairy herds. Magyar Állatorvosok Lap$j a, 2016$, vol. 138, issue 11, pp. 653-662. (in Hungarian)

7. Fodor I., Cziger Zs., Ózsvári, L. Economic analysis of the application of reproductive ultrasound examinations on a large-scale dairy farm. Magyar Állatorvosok Lapja, 2016, vol. 138, issue 9, pp. 515-522. (in Hungarian)

8. Fodor I., Ózsvári L. Early pregnancy diagnosis in dairy herds and its economic importance. Magyar 
Állatorvosok Lapja, 2017, vol. 139, no. 1, pp. 3-15. (in Hungarian)

9. Heersche G., Nebel R. L. Measuring efficiency and accuracy of detection of estrus. Journal of Dairy Science, 1994, vol. 77, issue 9, pp. 2754-2761. DOI: $10.3168 /$ jds.S0022-0302(94)77218-0.

10. Kranjec F., Fodor I., Földi J., Ózsvári L. Comparative analysis of the reproductive performance of dairy herds based on standardized parameters in Hungary. Magyar Állatorvosok Lapja, 2016, vol. 138, issue 8, pp. 451-462. (in Hungarian)

11. National Food Chain Safety Office, Livestock Performance Testing Ltd. Standard lactational milk yield 2016. National Cattle Database, 2017.

12. Norman H. D., Wright J. R., Hubbard S. M., Miller R. H., Hutchison J. L. Reproductive status of
Holstein and Jersey cows in the United States. Journal of Dairy Science, 2009, vol. 92, issue 7, pp. 3517-3528. DOI: $10.3168 /$ jds.2008-1768.

13. Ózsvári L., Kerényi J. Quantification of losses due to reproductive disorders on a large-scale HolsteinFriesian dairy farm. Magyar Állatorvosok Lapja, 2004, vol. 126, issue 9, pp. 523-531. (in Hungarian)

14. R Core Team. R: A Language and Environment for Statistical Computing. R Foundation for Statistical Computing, Vienna, Austria, 2016. Available at: http://www.R-project.org

15. Roelofs J., López-Gatius F., Hunter R. H. F., Eerdenburg van F. J. C. M., Hanzen C. When is a cow in estrus? Clinical and practical aspects. Theriogenology, 2010, vol. 74, issue 3, pp. 327-344. DOI: 10.1016/j.theriogenology.2010.02.016. 